\title{
Social participation and life satisfaction among older adults: diversity of practices and social inequality in Switzerland
}

\author{
Marie Baeriswyl ${ }^{1 \star}$ (D) and Michel Oris ${ }^{1,2}$ \\ ${ }^{1}$ Swiss National Centre of Competence in Research LIVES - Overcoming Vulnerability: Life Course \\ Perspectives (NCCR LIVES), Centre for the Interdisciplinary Study of Gerontology and Vulnerability \\ (CIGEV), University of Geneva, Geneva, Switzerland and ${ }^{2}$ Institute of Demography and Socioeconomics, \\ University of Geneva, Geneva, Switzerland \\ *Corresponding author. Email: marie.baeriswyl@unige.ch
}

(Accepted 15 June 2021)

\begin{abstract}
This paper examines the associations between social participation and individual life satisfaction among older adults. It specifically considers the diversity of the practices and social inequalities among this population. For analyses, we used a large survey of individuals of 65 years and older conducted in 2011 in Switzerland $(\mathrm{N}=2,727)$. The first set of linear regression analyses examines Diener's Satisfaction with Life Scale and its association with various indicators of social participation. While the second set of logistic regression addresses the issue of social inequalities by evaluating the impacts of gender, age group, region and education on social participation indicators that are significantly associated with the satisfaction with life score. Our results stressed the importance of combining multiple forms of participation for life satisfaction and shows that some forms are particularly meaningful: in particular, the involvement in associations, visitation of family or visitation of friends/ acquaintances and church attendance. When inequalities among older adults are considered, having rich and varied social participation, being involved in associations and maintaining private sociability with non-kin appear more elitist. While institutionalised and/or private sociability types of participation appear particularly significant for older adults' life satisfaction, the most traditional integration forms - i.e. family and religions - are crucial for the more vulnerable. Implications for active ageing was equally discussed as well.
\end{abstract}

Keywords: life satisfaction; active ageing; social activities; heterogeneity; inequalities

\section{Introduction}

This paper is aimed at increasing the understanding of the relationships between social participation and life satisfaction after retirement, considering both the diversity of involvements in social life and the social inequalities among older adults.

\footnotetext{
(C) The Author(s), 2021. Published by Cambridge University Press. This is an Open Access article, distributed under the terms of the Creative Commons Attribution-NonCommercial-NoDerivatives licence (http://creativecommons.org/ licenses/by-nc-nd/4.0/), which permits non-commercial re-use, distribution, and reproduction in any medium, provided the original work is unaltered and is properly cited. The written permission of Cambridge University Press must be obtained for commercial re-use or in order to create a derivative work.
} 
These embedded issues contribute to the reflection on the concept of active ageing that has become dominant in the last few decades, while social participation - broadly defined as individual involvement in activities implying interaction with others (Levasseur et al., 2010) - gained prominence in ageing representations and realities (Agahi and Parker, 2005; Ajrouch et al., 2007; Raymond et al., 2008; Einolf, 2009; Broese van Groenou and Deeg, 2010; Baeriswyl, 2017). In particular, social participation seems closely related to the issues of individual wellbeing - or the fact of 'feeling good and functioning well' (Ruggeri et al., 2020: 1) - at this lifestage.

Initially, around the mid-20th century in the Western world, the institutionalisation of retirement supported a withdrawal from active life, which was largely considered as a withdrawal from social life. This was the argument of the disengagement theory (Cumming and Henry, 1961), which posits that the withdrawal of older adults from all spheres of life was inevitable and necessary. The extension of longevity, improvement of health and living conditions, and debates about demographic ageing and its impact on both intergenerational solidarity and the welfare state have progressively contributed to changing expectations (Mendes, 2013). In the last part of the 20th century, ageing representations saw the emergence of a 'third age' associated with autonomy, activity and personal achievement, while negative representations of old age were postponed to a 'fourth age' (Laslett, 1987). Over this period, the initiators of the influential 'successful ageing' model, Rowe and Kahn $(1987,1997)$, gave a central place to activity among the factors allowing older adults to overcome age-related losses associated with 'normal ageing'. In this context, individual wellbeing emerged as a new political ambition for old age and the capacity to remain active became the condition for this wellbeing (Collinet and Delalandre, 2014). Upon these foundations emerged the concept of 'active ageing', promoting older adults' social participation and appearing as an overall response to new ageing realities (Walker, 2002), with a 'win-win' gain for both individuals and societies (van Dyk et al., 2013).

Despite an apparent broad consensus, this concept involves different approaches (Walker, 2009; Mendes, 2013; Zaidi and Howse, 2017). According to the World Health Organization (WHO, 2002: 12), active ageing aims for 'people to realise their potential for physical, social, and mental well-being throughout their life course and participate in society according to their needs, desires and capacities, while providing them with adequate protection, security and care when they require assistance'. If individual wellbeing is central to this WHO perspective, active ageing can likewise be further promoted in terms of savings and gains. For instance, the European Commission (nd) has defined active ageing as 'helping people stay in charge of their own lives for as long as possible as they age and, where possible, to contribute to the economy and society'. This definition reflects a more reductive and utilitarian vision of social participation.

Critically, different authors have reported prescriptivism under the active ageing concept. By promoting a certain ideal of ageing, active ageing policies empower the individual about this lifestage while legitimising one way of behaving (Moulaert and Biggs, 2013). However, not all older adults, depending on their resources and way of life, are able or want to conform to what is valued by scientific and political discourses (van Dyk et al., 2013). Thus, although the discourses on active ageing have contributed to promoting a more positive picture of ageing and value of 
older adults' social roles, the associated risks of exclusion and marginalisation for those who do not conform should be seriously considered (Zaidi and Howse, 2017; Del Barrio et al., 2018).

More so, this paper contributes to this discussion by examining the links between the older adults' life satisfaction and their social participation, considering explicitly the diversity of practices and the social inequalities in their access. Life satisfaction refers to the overall assessment by the individual of their quality of life according to their own criteria. Through this measure, we focus on the subjective wellbeing (SWB) of older adults (Diener et al., 1985; Oishi et al., 2018), in other terms the self-reported evaluation of wellbeing. This dimension has become a key element of the assessment of 'ageing well' (Collinet and Delalandre, 2014; Jivraj et al., 2014). This increasing interest has resulted in various measures of SWB, effectively distinguishing between emotional (or affective) and cognitive (evaluative) dimensions. Life satisfaction belongs to the second category and is described as more stable and less affected by transient moods than the first one (Dolan et al., 2008). ${ }^{1}$ Life satisfaction is considered a good indicator of psychological adaptation to the ageing process and successful ageing (Gutiérrez et al., 2013; Li et al., 2016). Consequently, it would be appropriate to question the associations between social participation and the individual sense of wellbeing.

Empirically, based on a large survey on the health and living conditions of older adults (aged 65 years and older) in Switzerland, we essentially addressed our questioning in two stages, asking first what participation forms are associated with life satisfaction, and then how belonging to certain social categories shape access to these forms of participation. In the following sections, we deepen the rationale of our research questions through a focused literature review; thereafter we discuss the data and methods. Results indicate the complexity of the association between social participation and life satisfaction. They sustain a discussion about the meaning of having some multiple and various participations, on the one hand, and some specific participations types involving institutionalised ties and/or private sociability forms, on the other hand. Moreover, findings of social inequalities in participation opportunities lead to making a difference between more or less traditional forms of participation, new ones similarly emerging overall as more unequal. We conclude by re-examining social participation diversity and social inequalities linked with the active ageing discourses, underlining the importance of the cohort change and its implications for future generations of older people.

\section{Social participation and life satisfaction: a literature review}

\section{Multiplicities and complexities of ties between social activities and SWB}

The associations between social participation and several dimensions of health, including SWB and life satisfaction measures, have been repeatedly observed (Bath and Deeg, 2005; Raymond et al., 2008; Morrow-Howell, 2010; Cutler et al., 2011; O’Neill et al., 2011; Dorfman, 2013; Douglas et al., 2017; Hornby-Turner et al., 2017). Their conclusions are however not completely coherent. One reason for this variability refers not only to the various indicators of wellbeing and SWB studied but also the multiple ways of conceptualising and defining social 
participation (Bath and Deeg, 2005; Raymond et al., 2008; Douglas et al., 2017). Studies have considered simultaneously various activities and their links with SWB (Li and Ferraro, 2005; Choi et al., 2013; Potočnik and Sonnentag, 2013; Amagasa et al., 2017; Vozikaki et al., 2017), particularly life satisfaction (Chen, 2001; Warr et al., 2004; Joulain et al., 2019; Ramia and Voicu, in press), and have confirmed that not all the types of social participation show a similar and positive association.

Overall, the mechanisms involved in a positive influence of social participation on older adults' wellbeing are not clearly established. Raymond et al. (2008) distinguished three types of explanations. The first advances that social participation allows older adults to keep fit by supporting cognitive and/or physical activity, which influences SWB indirectly (Helliwell and Putnam, 2004). The second considers social participation as an identity resource that contributes to overcoming losses and bereavements associated with ageing by providing recognised social roles (see also Van Willigen, 2000; Morrow-Howell et al., 2003; Li and Ferraro, 2005; Choi et al., 2007). The last type of explanation focuses on social relations benefits in the ageing process: the contacts and significant mutual exchanges in social participation are described as ways to find goals and consequently to maintain meaning in life.

These mechanisms are not exclusive and can be more or less present depending on the specific activity being performed. For instance, formal public participation, such as being active in associations or formal volunteer work, seems particularly meaningful to occupy a recognised social role (Li and Ferraro, 2005; MorrowHowell, 2010), and thus contribute to individuals' sense of wellbeing. Various empirical studies have confirmed its association with older adults' SWB (Morrow-Howell et al., 2003; Greenfield and Marks, 2004; Potočnik and Sonnentag, 2013; Barbabella et al., 2019), and specifically with their satisfaction of life (Van Willigen, 2000; Helliwell and Putnam, 2004; Lee and Choi, 2020; Ramia and Voicu, in press). Among social relations, some contexts appear more relevant for wellbeing; in the last decades, marked by a growing prevalence of social norms promoting individuality against institutions (Giddens, 1991), friendships ties emerged as particularly meaningful in terms of SWB and life satisfaction because they are independent of constraint and obligation when compared with family ties (Krause, 2010; Carr and Moorman, 2011; Huxhold et al., 2014). Consequently, friendly relationships tend to last only as long as they are perceived as positive (Allan, 2008). In contrast, studies on care-giving have shown that family roles could even be detrimental for SWB (concerning particularly life satisfaction, see Ramia and Voicu, in press). Involvements in other social activities may be important by providing a network of meaningful relationships: this is especially the case with religious participation, which supports values and specific individual behaviours contributing to SWB (Ellison, 1991; Lim and Putnam, 2010) and specifically to life satisfaction (Ellison et al., 2001; Warr et al., 2004). Besides, involvement in multiple roles could be particularly beneficial for individual wellbeing by increasing an 'individual's social network, power, prestige, resources, and emotional gratifications' (Moen et al., 1992: 1634; see also Baker et al., 2005; Douglas et al., 2017). Furthermore, studies have confirmed a higher level of life satisfaction for individuals accumulating several activities (Warr et al., 2004; Gilmour, 2012). 
This diversity of results and potential mechanisms underlines the complexity of the links between social participation and SWB, including life satisfaction, significantly with the many realities behind the concept of 'social participation'.

\section{Definitions of social participation: multiple boundaries and issues}

Studies on the concept of social participation have confirmed the lack of a clear universally accepted definition of the term (Larivière, 2008; Raymond et al., 2008; Levasseur et al., 2010). Social participation refers broadly to individual involvement in activities that entail interaction with others (Levasseur et al., 2010), however, various focuses co-exist in specific studies. Levasseur et al. (2010) distinguished six levels of social participation dependent on the proximity with others (alone, in parallel, in interaction) and aims of the activity (basic need, socialisation, task completion, the support provided to others or the society). Accordingly, Raymond et al. (2008) distinguished four sets of definitions that refer to the dynamics of the relationships between individuals and their environment. In the broadest sense, social participation is defined as daily functioning, while in the most restrictive sense, it is defined as structured associativity (or formal public participation). Between these two extremes, the researchers also distinguished social participation as social interactions (or social connectivity) and social networks (personalised social interactions referring to social capital and informal volunteering).

Ultimately, these studies underline the multi-dimensional aspect of social participation. In gerontology, a majority of studies have examined structured associativity (Raymond et al., 2008) or in a slightly broader perspective, social commitment (Levasseur et al., 2010). Thus, we can draw a parallel with issues that are central to the definition of active ageing content: clearly, the most restrictive definition - formal public participation - is the most popular in political discourses (Walker, 2009; Moulaert and Biggs, 2013; Del Barrio et al., 2018). This perspective refers to a 'productive' model of ageing or, more broadly put considering alongside informal commitment, to a 'solidary' model of ageing (Backes and Amrhein, 2008). Both models primarily support the 'useful' character of older adults' activities. However, several studies have shown the importance of more informal and/or private activities in terms of both older adults' practices (Suanet et al., 2013; Baeriswyl, 2017) and their SWB outcomes (Bickel and Girardin Keciour, 2008), including life satisfaction (Chen, 2001; Gutiérrez et al., 2013; Huxhold et al., 2014; Yuan, 2016; Ramia and Voicu, in press). Thus, these forms of participation should equally be considered as important investments at retirement time in the individual wellbeing perspective.

On a more theoretical level, the study of two sets of distinctions - between private and public spheres, and between formal and informal participation - revealed ambivalent issues about the meanings attached to various investments in terms of empowerment versus confinement/domination. First, the private/public distinction, which is crucial in the study of gender relations and inequalities, can generally be seen as a continuum, ${ }^{2}$ combining two criteria where the private is opposed to the visible and collective character of the public (Weintraub, 1997). The public dimension of investments emerges thus as a privileged place for social recognition and is often conceived in that perspective as crucial for self-realisation (see the section above on SWB). However, conversely, the private does not refer only to simple 
negative withdrawal but should be thought of as emancipatory and 'satisfactory' through its more individual aspects (as opposed to public constraints or public desingularisation) (Schwartz, 1990). For retired people, more private investments may particularly mean work liberation and time for themselves.

The second level of distinction refers to structural dimensions of participation. Several authors have distinguished particular relational structures, the social circles, from social networks or relationships (Grossetti, 2005; Bidart et al., 2011). Social circles involve institutionalised forms of social ties in which individual position and status are defined, borders are clear and stable, and forms of collective identification are shared. This distinction refers to more or less formal forms of participation indirectly mentioned above as 'structured associativity', and family or religious participation too. For the individual, social circles represent both resources and constraints (Bidart et al., 2011) and involve mixed issues regarding SWB, particularly in the context of late modern societies where individuality is promoted against the institutions (Giddens, 1991). This is well expressed through the concept of ambivalence in intergenerational relationships that spotlights the adverse feelings that can arise from the co-existence within family dynamics of norms and practices of solidarity and interdependency, on the one hand, and autonomy and independence, on the other hand (Lüscher and Pillemer, 1998).

\section{An inclusive and plural approach of social participation}

At this stage, we conclude that adopting a more inclusive definition of social participation while considering its multi-dimensional character and various contents is important to understand better its relations to life satisfaction. In this framework, we propose to understand social participation as any activity undertaken voluntarily by an individual that includes a relation with other persons. Given the background on various social participation opportunities, we can distinguish formal public participation forms that constitute the most restrictive definition of social participation in the literature (Raymond et al., 2008) and refer to the civic dimension of the 'public' definition as a means of intervention in collective life (Weintraub, 1997), embodying both characteristics related to this sphere - that is visible and collective. Additionally, it implies mainly the integration to specific circles, notably associative.

Besides, we can distinguish more informal participation in the public sphere similarly studied in the literature in terms of social leisure, that is not aimed towards the 'collective' but refers to some impersonal sociability (Weintraub, 1997) or socialisation in parallel (Levasseur et al., 2010). This dimension of social participation involves more exclusively expressive practices compared to formal public participation. In particular, cultural activities can be seen as typical of contemporary society based on consumption and personal achievement (Bickel et al., 2005). Other activities - typically going to the café - represent a more communitarian and traditional aspect of these forms of social participation.

Other social participation forms refer more directly to the private as the sphere of intimate and interpersonal relationships (Weintraub, 1997). Both 'invisible' and 'individual', private sociability refers to expressive activities involving personal relationships and represents the counterpart of social leisure in private space, often 
studied in terms of a personal network. This more invisible aspect of social participation has a collective aspect through support practices that are studied as informal volunteering'. These forms of social participation represent the less visible, and less recognised, side of social commitment, in comparison with the formal public dimension (Pennec, 2004). In addition, considering the structural aspects of participation, the distinction between activities involving family or non-kin (typically friends) ties refer to the more or less institutionalised dimensions of private participation.

Finally, religious social participation (typically office attendance) occupies a special position: it takes place outside the home and the intimate sphere, which, however, refers neither to civic engagement nor to impersonal sociability. It refers to the inclusion in a specific circle involving a community based on shared beliefs and values. It provides specific opportunities for meaningful exchange, social support and recognition (Baumann, 2012).

Beyond the distinction of various forms of investments in social ties, the accumulation of individual investments is another interesting point to consider regarding life satisfaction. The possibility to combine many different forms of social integration is, as Simmel (2009) stressed, a central element in the modernity process as a major motor of individualisation. Combining multiple forms of social participation should thus be important for self-realisation and SWB.

\section{Individualisation and unequal individuals}

As previously stated, social participation issues related to SWB and life satisfaction can vary depending on the adopted definition of social participation. Further, from the perspective of more critical gerontology (Baars et al., 2005), it is important to consider the heterogeneity of the older adult population (Oris et al., 2016) and the social inequalities that impact life conditions after retirement (Oris et al., 2017). The process of individualisation - in which social and cultural changes occurred in postwar Western societies have notably established self-realisation as a lifecourse ideal (Honneth, 2004) - , is sometimes described as involving a decline in logics of inequalities (e.g. Beck and Willms, 2004, on the idea of classes' erasure). Rather, empirical studies have emphasised the persistence of inequalities (e.g. Blossfeld et al., 2015, on the impact of social origin on educational attainment; or Krüger and Levy, 2001, regarding gendered lifecourses), particularly in old age, where a cumulative process may even increase social inequalities (Dannefer, 2020).

Studies have underlined social participation as conditioned by a set of social determinants that include gender, age or socio-economic status (Morrow-Howell, 2010; Cutler et al., 2011; O’Neill et al., 2011; Dorfman, 2013). Furthermore, previous research comparing various forms of participation has shown that such determinants and their impact may vary depending on the type of activity (Wilson and Musick, 1997; Agahi and Parker, 2005; Bickel and Cavalli, 2008; Broese van Groenou and Deeg, 2010; Baeriswyl, 2017, 2018). For instance, access to public formal activities, such as volunteering or membership of associations that are socially valued forms of social participation, seems more socially stratified or, simply put, more unequal. Thus, the inclusive and multi-dimensional approach adopted in this paper is pertinent regarding the issues of social inequalities. 


\section{Methods}

\section{Data}

The empirical analyses are based on data from the survey 'Vivre-Leben-Vivere: Old Age Democratization? Progresses and Inequalities in Switzerland' (VLV). This large interdisciplinary survey on living and health conditions of people aged 65 and older was conducted in 2011/2012 in five Swiss cantons (Geneva, Valais, Bern, Basel and Ticino). These regions are representative of the country's diversity on territorial, lingual and political levels (for more details on the characteristics of these regions, see Table 1; for more details on the VLV survey, see Ludwig et al., 2014). The VLV data have already been exploited in more than 80 publications. ${ }^{3}$

The sample was randomly selected from regional population registers and was stratified by gender and age group (65-69, 70-74, 75-79, 80-84, 85-89 and 90 years and older). In this context, all the following analyses use a computed weighting coefficient to restore the real population structure (StataCorp, 2011). Data were collected through two standardised questionnaires, one auto-administered and one filled in during a face-to-face interview. Overall, 3,080 individuals answered personally (for a complete assessment of the VLV survey, see Oris et al., 2016). Among those, we excluded from the working sample 353 who did not respond to all the items of the Diener life satisfaction scale, leaving us with 2,727 older adults.

\section{Variables}

\section{Life satisfaction}

We analysed the life satisfaction of older adults using the Satisfaction with Life Scale developed by Diener et al. (1985). This scale is composed of five items through which an individual is asked to evaluate life satisfaction based on his or her own criteria:

(1) In most ways my life is close to my ideal.

(2) The conditions of my life are excellent.

(3) I am satisfied with my life.

(4) So far I have gotten the important things I want in life.

(5) If I could live my life over, I would change almost nothing.

Participants had to indicate how much they agreed or disagreed with each item using a seven-point scale, with seven meaning 'strongly agree' and one 'strongly disagree'. The answers were added to an individual score.

Analysis of Cronbach's alpha (0.85) and principal component analysis (the first axe explaining $64 \%$ of the variance) confirmed the overall consistency of individual answers. A mean satisfaction with life value of 26.8 and standard deviation of 5.4 showed VLV results close to those found for older adults in other studies (Blais et al., 1989; Pavot and Diener, 1993, 2009).

\section{Participation variables}

In coherence with the previous theoretical discussion, we constructed 12 binary indicators of social participation. Original variables consisted of different frequency scales. We dichotomised them to render information on access to the activities in 
Table 1. Surveyed regions' main characteristics

\begin{tabular}{lllll}
\hline Region & Type & Historical confession & Majority language & $\begin{array}{c}\text { Tertiary } \\
\text { education }^{2}(\%)\end{array}$ \\
\hline Geneva & Urban & Protestant & French & 39 \\
\hline Valais & Semi-urban & Catholic & French & 23 \\
Bern & Semi-urban & Protestant & German & 27 \\
Basel & Urban & Protestant & German & 32 \\
\hline Ticino & Semi-urban & Catholic & Italian & 26 \\
\hline
\end{tabular}

Notes: 1. Majority confession may differ from historical one. However, historical confessions always influence the institutional and cultural frameworks of each region (Monnot, 2013). 2. Proportion of people with tertiary education among the resident population aged 25 years and older in 2012 (Office fédéral de la statistique (OFS), nd).

Source: Table taken from Duvoisin (2020: 47, own translation) and completed with data derived from the OFS.

question. More specifically, we set bounds that assumed a minimal regularity, that is, their practice was not exceptional, and, however, a high frequency was not necessarily required. Often, the frequency chosen was monthly; however, it depended on the nature of the activity and the original variable response modalities (Table 2).

The first three indicators (being involved in associations, doing volunteer activities, and attending political or trade union demonstrations; 1-3 in Table 2) are forms of social commitment in the public sphere. They refer mainly to civic participation and the most restrictive definition of social participation as formal public participation. The next four indicators (4-7) are more individual forms of participation in the public sphere, referring to more informal and unilaterally expressive social activities involving a certain integration in society. Primarily, going to the cinema/concert/theatre and attending classes/conferences represent activities more typical of contemporary culture; the two other indicators - going to neighbourhood or village parties and going to cafés/tearooms/restaurants - represent a more communitarian and traditional form of social participation. Another form of participation that can be considered traditional in the European context is the church/temple, etc. attendance (8). As noted above, it represents a specific form of participation in the public sphere, neither 'collective' nor 'impersonal', and refers to a particular social circle. The last four indicators (9-12) refer to forms of participation in the private sphere of intimacy and interpersonal relationships: they are differentiated by whether they take place within the family circle or in non-kin networks and whether they imply the collective dimension of social commitment (helping) or not (visiting), referring in the last case to more exclusively expressive practices of sociability. Additionally, we constructed a score representing the sum of the 12 binary indicators to document the individual accumulation of practices.

\section{Control variables}

The various control variables introduced in the analyses of the links between social participation and life satisfaction refer first to the three socio-demographic variables that were used to stratify the VLV sample: sex, age group and region. A second group includes other individual characteristics that constitute, as previous research has shown, resources for both life satisfaction (Pinquart and Sörensen, 2000; Dolan 
Table 2. Social participation variables and distribution among the survey population

\begin{tabular}{|c|c|c|c|c|}
\hline \multicolumn{2}{|c|}{ Participation type } & \multirow{2}{*}{$\begin{array}{l}\text { Participation criteria } \\
\text { Going monthly to reunions } \\
\text { or having responsibility }\end{array}$} & \multirow{2}{*}{$\frac{N}{790}$} & \multirow{2}{*}{$\begin{array}{c}\begin{array}{c}\text { Distribution } \\
(\%)^{1}\end{array} \\
32\end{array}$} \\
\hline 1 & Being involved in an association ${ }^{2}$ & & & \\
\hline 2 & Doing volunteer activities & At least occasionally & 636 & 27 \\
\hline 3 & $\begin{array}{l}\text { Attending political or trade union } \\
\text { demonstrations }\end{array}$ & At least once a year & 449 & 18 \\
\hline 4 & $\begin{array}{l}\text { Going to the cinema, concert, } \\
\text { theatre }\end{array}$ & At least once a month & 832 & 36 \\
\hline 5 & Attending classes, conferences & At least once a month & 412 & 18 \\
\hline 6 & $\begin{array}{l}\text { Going to cafés, tearooms, } \\
\text { restaurants }\end{array}$ & At least once a month & 2,106 & 81 \\
\hline 7 & $\begin{array}{l}\text { Going to neighbourhood or village } \\
\text { parties }\end{array}$ & At least once a year & 1,215 & 50 \\
\hline 8 & Going to church/temple, etc. & At least once a month & 968 & 35 \\
\hline 9 & Visiting family members & At least once a month & 1,660 & 64 \\
\hline 10 & Visiting friends, acquaintances & At least once a month & 1,515 & 60 \\
\hline 11 & $\begin{array}{l}\text { Helping family members (living } \\
\text { outside their home) }\end{array}$ & $\begin{array}{l}\text { At least one service } \\
\text { sometimes }\end{array}$ & 1,541 & 64 \\
\hline 12 & $\begin{array}{l}\text { Helping friends, acquaintances, } \\
\text { neighbours (living outside their } \\
\text { home) }\end{array}$ & $\begin{array}{l}\text { At least one service } \\
\text { sometimes }\end{array}$ & 995 & 42 \\
\hline
\end{tabular}

Notes: 1 . Weighted data. 2. This variable is based on three questions: a list of types of associations to which individuals can be member, the frequency of participation to associations meeting and the fact of having responsibility in associations. 3. This variable is based on a list of ten types of service that individuals can provide: cleaning, preparing/ bringing meals, shopping, providing child care/helping with homework, doing home repairs/tinkering/gardening, taking children on outings, taking old or disabled persons on outings, helping with professional work, helping with grooming, helping with administrative tasks.

et al., 2008; George, 2010) and social participation (Raymond et al., 2008; Morrow-Howell, 2010; Cutler et al., 2011; O’Neill et al., 2011; Dorfman, 2013). Education level (compulsory, upper secondary, tertiary) and access to more than basic old-age pension (yes/no) ${ }^{4}$ refer to the individual socio-economic position in the structures of the retired population; frailty score (Guilley et al., 2008) and depression score (adapted from Wang et al., 2002; see also Lalive d'Epinay et al., 2000) refer to health capacities, both physical and psychological; household composition (married, not married and living alone, not married but co-habiting); presence of descendants (none, having at least one living child, having child(ren) and at least one grandchild) and presence of close friend(s) (yes/no) in the individual network refer to social capital (Table 3).

\section{Indicators of social inequalities}

Among the presented control variables, the three socio-demographic characteristics (sex, age group and region) are used as independent variables in the second set of analyses that examine social inequalities in participation opportunities. 
Table 3. Surveyed population characteristics

\begin{tabular}{llcl}
\hline Variables & Modalities & $\%$ & Mean (SD) \\
\hline Education level & Compulsory & 17 & \\
& Upper secondary & 54 & \\
& Tertiary & 29 & $1.13(1.24)$ \\
\hline Income & Having a second/third pillar & 75 & $0.94(1.35)$ \\
\hline Fragility score & $0-5$ & & \\
\hline Depression score & $0-9$ & & \\
\hline Household & Married & 61 & \\
& Non-married living alone & 30 & \\
\hline Descendants & Non-married co-habiting & 15 & \\
& None & 15 & \\
\hline Friends & At least one child & 70 & \\
\hline
\end{tabular}

Notes: Weighted data. SD: standard deviation.

Subsequently, we selected the education level that constitutes a good and reliable proxy of socio-economic status in old age (Oris et al., 2017).

\section{Analyses}

We ran two sets of linear regression models on the score of life satisfaction. In the first one, the 12 binary indicators of social participation were tested, and in the second, the score resulting from the sum of those 12 indicators. For both analyses, we ran two nested models: in the first model, the three socio-demographic variables of sample stratification (age, sex and region) and the participation indicators (activities or score) were included. In the second model, we added all the other control variables ('resources variables') presented above to isolate the association between social participation and life satisfaction from a broader resources system (that can influence both participation and life satisfaction).

Thereafter, we ran a series of regression analyses on the indicators of social participation revealed to be significantly linked with life satisfaction to address the issue of social inequalities. Specifically, we ran logistic regressions on the binary participation indicators and Poisson regression on the score of participation.

\section{Results}

\section{Social participation distribution}

Overall, the mean value of the social participation score is 5.22 out of a maximum of 12 , and its standard deviation is 2.42 . Regarding the distribution of the various practices of social participation among our study population (Table 2), sociability 
practices in public (going to café or local event) and private (visiting family or friends) spheres are the most common, concerning a majority of the older adults. The other expressive practices, i.e. cultural leisure, are less frequent and engage only a minority of the people of retirement age. Among the forms of commitment towards others, a majority of older adults offer occasional help to family members living outside the home. Social commitment in the public sphere is rarer than in the private sphere: about one-third of older adults declare being involved in associations, while fewer do volunteer activities and even fewer take part in political or trade union demonstrations. Finally, religious participation concerned about one-third of older people.

\section{The links between social participation and life satisfaction}

The general importance of participation for life satisfaction is confirmed when we consider its links with the score of participation: multi-activity and life satisfaction are positively associated (Table 4, 'Score' column). Although the coefficient is reduced in Model 2 , showing that part of the link between the life satisfaction and social participation score can be explained by other individual resources, a significant link remains.

The analyses of life satisfaction related to the different types of participation show more or less significant results (Table 4, 'Activities' column). Namely four types remain significant and positively linked to this measure of cognitive SWB after controlling for the aforementioned various resources (Model 2): being involved in an association, visiting family, visiting friends/acquaintances and going to church/temple, etc. Attending shows (cinema, concert, theatre) and helping family members have a significant positive association with life satisfaction in Model 1. However, this association disappears when controlled for the various resources of older adults. An unexpected result concerns attending courses or conferences: this type of activity has a significant negative association with life satisfaction.

\section{Social inequalities in social participation}

Table 5 shows significant results concerning social participation and life satisfaction when considering unequal chances to participate according to gender, region, age and level of education. The overall score is not differentiated between men and women; however, the types of participation refer to gender differences. Men are more likely to invest in associations; women are more likely to visit friends or acquaintances and to go to church/temple, etc. Family sociability, however, is not impacted by gender.

In terms of region, we also found specificities in participation types. People living in the canton of Geneva - which is typical of an urban, laic and socioeconomically advanced regional context - are significantly more likely to have associative involvement and are less likely to have religious or family participation. They are also significantly more likely to visit friends or acquaintances than people living in the Catholic and less socio-economically developed regions of Valais and Ticino.

The effect of age on participation likelihood is markedly negative (as shown by the score results). However, in contrast with this general trend, going to church/ temple, etc. is positively associated with older age groups. This result underlines a cohort effect. The comparison of this practice in 2011 with comparable data from 1979 clearly showed its decline across the birth cohorts (Baeriswyl, 2017). 
Table 4. Multiple linear regression analyses on the Satisfaction with Life Scale - the links with social participation

\begin{tabular}{|c|c|c|c|c|}
\hline & \multicolumn{2}{|c|}{ Score } & \multicolumn{2}{|c|}{ Activities } \\
\hline & Model $1^{1}$ & Model $2^{2}$ & Model $1^{1}$ & Model $2^{2}$ \\
\hline & \multicolumn{4}{|c|}{ Standardised beta coefficients } \\
\hline Participation score & $0.46^{\star \star \star}$ & $0.23^{\star \star \star}$ & & \\
\hline Being involved in an association & & & $1.00^{\star \star \star}$ & $0.66^{\star \star \star}$ \\
\hline Doing volunteer activities & & & 0.45 & 0.14 \\
\hline $\begin{array}{l}\text { Attending political/trade union } \\
\text { demonstrations }\end{array}$ & & & 0.35 & 0.33 \\
\hline Going to the cinema, concert, theatre & & & $0.60^{\star *}$ & 0.09 \\
\hline Attending classes, conferences & & & $-0.64^{\star \star}$ & $-0.48^{\star}$ \\
\hline Going to cafés, tearooms, restaurants & & & 0.15 & -0.31 \\
\hline $\begin{array}{l}\text { Going to neighbourhood or village } \\
\text { parties }\end{array}$ & & & 0.25 & 0.09 \\
\hline Going to church/temple, etc. & & & $0.46^{\star}$ & $0.38^{\star}$ \\
\hline Visiting family members & & & $0.99^{\star \star *}$ & $0.76^{\star \star \star}$ \\
\hline Visiting friends, acquaintances & & & $0.79^{\star \star \star}$ & $0.68^{\star \star \star}$ \\
\hline Helping family members & & & $0.84^{\star \star \star}$ & 0.31 \\
\hline $\begin{array}{l}\text { Helping friends, acquaintances, } \\
\text { neighbours }\end{array}$ & & & -0.18 & -0.27 \\
\hline Constant & $23.45^{\star \star \star}$ & $25.49^{\star \star \star}$ & $23.31^{\star \star \star}$ & $25.73^{\star \star \star}$ \\
\hline AIC & $15,230.84$ & $14,844.36$ & $15,212.06$ & $14,832.81$ \\
\hline $\mathrm{BIC}$ & $15,300.61$ & $14,972.27$ & $15,345.78$ & $15,024.67$ \\
\hline
\end{tabular}

Notes: $\mathrm{N}=2,475$. Weighted data. 1. Control variables: gender, age group and region. 2. Control variables: gender, age group, region, education level, income source, fragility score, depression score, household composition, descendants, close friend existence. AIC: Akaike information criterion. BIC: Bayesian information criterion.

Significance levels: ${ }^{\star} p<0.1,{ }^{\star \star} p<0.05,{ }^{\star \star \star} p<0.01$.

Taking into perspective the educational level impact, the overall advantage of an elite group emerges. Possessing a tertiary diploma increases the likelihood of participating in a wide variety of activities. More specifically, having a high education has a positive effect on the probability of being involved in an association, and having an average education level, and much more a high level increases the likelihood of visiting friends or acquaintances. However, family sociability is not impacted by this individual socio-economic position and having a low level of education tends even to increase church attendance.

\section{Discussion}

The links between social participation and life satisfaction in old age are confirmed by the Swiss data while highlighting some specific aspects of the various social activities of the older adults as well as important issues related to social 
Table 5. Multiple regression analyses on participation indicators - the impact of socio-demographic and socio-economic positions

\begin{tabular}{|c|c|c|c|c|c|}
\hline & $\begin{array}{l}\text { Participation } \\
\text { score }^{1}\end{array}$ & $\begin{array}{l}\text { Visiting } \\
\text { family }^{2}\end{array}$ & $\begin{array}{l}\text { Visiting friends, } \\
\text { acquaintances }^{2}\end{array}$ & $\begin{array}{l}\text { Going to church/ } \\
\text { temple, etc. }\end{array}$ & $\begin{array}{l}\text { Being involved } \\
\text { in an association }{ }^{2}\end{array}$ \\
\hline Men & 0.98 & 0.92 & $0.51^{\star \star \star}$ & $0.67^{\star \star \star}$ & $1.33^{\star \star \star}$ \\
\hline \multicolumn{6}{|c|}{ Canton (Ref. Geneva): } \\
\hline Valais & 1.03 & $1.36^{\star \star}$ & $0.69^{\star \star \star}$ & $4.25^{\star \star \star}$ & $0.72^{\star \star}$ \\
\hline Bern & 0.96 & 1.23 & 1.01 & $1.32^{\star}$ & $0.65^{\star \star \star}$ \\
\hline Basel & 0.98 & $1.36^{\star \star}$ & 1.14 & $1.38^{\star \star}$ & $0.72^{\star \star}$ \\
\hline Ticino & 0.98 & 1.25 & $0.75^{\star \star}$ & $2.06^{\star \star \star}$ & $0.65^{\star \star \star}$ \\
\hline \multicolumn{6}{|c|}{ Age (Ref. 65-69): } \\
\hline $70-74$ & 0.97 & 0.97 & 1.08 & $1.40^{\star \star}$ & 0.88 \\
\hline $75-79$ & $0.91^{\star \star \star}$ & 0.81 & 0.89 & $1.78^{\star \star \star}$ & $0.80^{*}$ \\
\hline $80-84$ & $0.78^{\star \star \star}$ & $0.79^{\star}$ & $0.64^{\star \star \star}$ & $1.71^{\star \star \star}$ & $0.55^{\star \star \star}$ \\
\hline $85-89$ & $0.65^{\star \star \star}$ & $0.65^{\star \star \star}$ & $0.49^{\star \star \star}$ & $1.77^{\star \star \star}$ & $0.50^{\star \star \star}$ \\
\hline $90+$ & $0.47^{\star \star \star}$ & $0.35^{\star \star \star}$ & $0.25^{\star \star \star}$ & $1.40^{\star}$ & $0.28^{\star \star \star}$ \\
\hline \multicolumn{6}{|c|}{ Education (Ref. Upper secondary): } \\
\hline Compulsory & $0.86^{\star \star \star}$ & 0.87 & $0.65^{\star \star \star}$ & $1.24^{\star}$ & 0.80 \\
\hline Tertiary & $1.12^{\star \star \star}$ & 0.9 & $1.34^{\star \star \star}$ & 0.97 & $1.75^{\star \star \star}$ \\
\hline Constant & $5.80^{\star \star \star}$ & $1.83^{\star \star \star}$ & $2.68^{\star \star \star}$ & $0.25^{\star \star \star}$ & $0.60^{\star \star \star}$ \\
\hline AIC & $13,432.23$ & $3,878.20$ & $3,855.44$ & $3,658.02$ & $3,624.92$ \\
\hline $\mathrm{BIC}$ & $13,509.07$ & $3,954.94$ & $3,932.21$ & $3,734.74$ & $3,701.76$ \\
\hline $\mathrm{N}$ & 2,726 & 2,705 & 2,711 & 2,702 & 2,726 \\
\hline
\end{tabular}

Notes: Weighted data. 1. Poisson regression (incidence-rate ratio). 2. Logistic regression (odds ratio). Ref.: reference category. AIC: Akaike information criterion. BIC: Bayesian information criterion. Significance levels: ${ }^{\star} p<0.1,{ }^{\star \star} p<0.05,{ }^{\star \star *} p<0.01$. 
inequalities in participation likelihood. In this final section, after the first point on the main results linking activities to life satisfaction, we discuss in particular two characteristics shared by the types of social participation that are positively linked to life satisfaction. Then, we reconsider these results from the perspective of the social inequalities involved in access to participation opportunities. After an acknowledgement of the limits of our analyses, we conclude by re-examining the implications of the various definitions of social participation and the dominant active ageing discourses. Future challenges and questions about social participation and life satisfaction will be finally addressed.

\section{Social participations and life satisfaction}

First, our results confirmed the association between having a rich and varied social participation and higher life satisfaction. This pattern observed in Switzerland is consistent with previous studies examining various dimensions of SWB (see the literature review section). Generally, it supports theories underlining the significance of multiple and intersected belongings for individuals' identity building and personal achievement, namely allowing greater individuality (Simmel, 2009). Second, analyses similarly highlighted four types of social participation that are especially meaningful for life satisfaction: involvement in associations, attendance of religious celebrations, visits to family and visits to friends/acquaintances. For most of those results, our results align with previous studies from other countries (mainly from the Western world and Asia as well). As stated earlier in the literature review section, the positive association with civic commitment, religious participation or friendship are well documented in the literature on life satisfaction of older people (see also Dolan et al., 2008; George, 2010).

Our findings about family are, however, less obvious. Studies have shown some negative impacts of family investment on older adults' SWB (Choi et al., 2013; Huxhold et al., 2014; Ramia and Voicu, in press). Overall, family ties involve more constraints (both as constrained and constraining) and seem more ambivalent than non-kin relationships regarding SWB issues: they can be simultaneously not just an important source of support but also a source of tension by reducing the autonomy of older individuals (Lüscher and Pillemer, 1998; Baeriswyl et al., in press). However, our results establish a positive association between visiting family members and life satisfaction that underlines the emancipatory dimension of the family (Schwartz, 1990). Caution is, however, needed since our variable concerns only one type of sociability practice, which represents a relatively voluntary form of contact, and focuses on family members living outside the household.

Finally, a more unexpected result concerns the negative association between life satisfaction and activity in courses or conferences. In Switzerland, like elsewhere, there is a growing offer of such activity, as part of the institutional promotion of life-long learning, seen as sustaining the productive capacities of the older adults as well as their general wellbeing (Campiche and Kuzeawu, 2014; Formosa, 2019). More so, studies tend to confirm the positive impact of life-long learning on SWB (Narushima et al., 2018). Critical voices, however, assert the absence of reliable statistics on the participation, the gap between the participants' expectations and offers sometimes qualified as elitist and 'mindless' together, and older adults 
being taken as passive recipients (Formosa, 2011, 2012). Another hypothesis to explain our result is that people who have less SWB, specifically life satisfaction, seek solutions through this type of learning activity. However, further investigation is needed, especially taking into consideration the types and content of learning activities. However, this result is the most explicit illustration of the various and complex links existing between social participation and life satisfaction.

Collectively, our results highlight two more general important characteristics of social participation positively associated with satisfaction of life. On one side, they emphasise the significance of participation embedded in formal/institutionalised social ties. Participation in associations, family or religion refers to structured forms of social ties, to 'social circles' in which individual position and status are defined and borders are clear and stable (Bidart et al., 2011). In the literature review section, and the image of family dynamics mentioned above, we noted the ambivalent meaning that participation in social circles can have between resources and constraints. However, in our results the association with life satisfaction is positive. An explanation lies in the social identity theory which suggests that integrations in such circles offer a feeling of belonging, with strong meaning that would contribute to a greater sense of wellbeing (Haslam et al., 2009). Participation in such social structures can also be regarded as playing a role of 'facilitator' for other types of relationships and participation (Bidart et al., 2011) and would constitute central investments in older adults' lives. At the crossroads of these two functions, when considering the association of religious participation and life satisfaction, Lim and Putnam (2010: 929) showed thus the role of both the network built through religious attendance and the identity shared: 'the social contexts in which networks are forged and the identities shared in these networks matter'. This interpretation can be applied to other social circles.

On the other side, the results about private sociability in the family circle and with friends or acquaintances point out the significance of very private forms of social participation related to life satisfaction. This highlights the meaning of expressive, personal and intimate relationships after retirement (in this sense, see also the results of Warr et al., 2004). Furthermore, it refers to the issue of the quality of social ties involved in participation: having significant and reciprocal exchanges would support the perception of social support, self-esteem and positive affects (Raymond et al., 2008), which would also influence positively life satisfaction.

\section{Social inequalities of participation in a late-modern society}

As we suspected, analysing the social determinants of social participation supports a critical perspective on previous findings by underlining social inequalities. Having multiple and diversified forms of social participation is associated with higher life satisfaction; however, the so-called 'young old' and individuals with high education are more likely to benefit from such participation profiles. Likewise, the chances of being engaged in an association or of visiting friends/acquaintances follow the same logic. These forms of social participation all refer to roles and relationships that are particularly valued in late modernity societies. First, hyperactive seniors represent the ideal type of 'new' older adults - matching both with the multi-activity characterising contemporary lifestyles (Cingolani, 2012) and with the attribution of 
individual responsibility to age 'successfully' (and actively) (Rowe and Kahn, 1997). In the perspective of the new models of ageing, involvement in the public sphere embodies particularly the 'productive' view on active ageing, often privileged in political discourse (Walker, 2009; Moulaert and Biggs, 2013; Del Barrio et al., 2018), and responds to the injunction for older adults to not be a 'social burden'. Finally, the development of elective social and flexible ties, referring expressly to personal relationships outside the family, is also part of individualisation processes in late modern societies ${ }^{5}$ (Stevens and Van Tilburg, 2011; Suanet et al., 2013).

In contrast, family and religious participation - that may be regarded as traditional modes of participation and integration - emerge as important practices for groups considered more vulnerable, that is they have greater exposure to risks and stresses because they tend to have fewer resources, for instance in terms of health and revenues (Oris, 2017). This is notably the case for the less-educated older adults and older women (Oris et al., 2017; Baeriswyl, 2018). Visiting family members appears as 'democratic' social participation as it is not impacted by the level of education. Being involved in a religious circle is the only type of social participation that tends to be more frequent for those with a low education level. In addition, women are more likely to engage in religious participation.

Opportunities to participate are not equally distributed among men and women, trends showing a traditional division of gender roles. In particular, we found the traditional gendered opposition between the public and the private: women remain overrepresented in the private sphere of intimacy and interpersonal relationships by their higher trend of visiting friends and are relatively less present than men in public spaces through a lower associative involvement. Beyond the SWB issue, this observation has consequences for power relationships between genders as women have less access to spaces where collective interests can be defended (Baeriswyl, 2018). Furthermore, the trend of religious participation - women are more likely to attend religious celebrations - refers also to gendered role construction, particularly in this generation (Campiche, 1996). Noteworthy, gender inequalities are transversal with those related to socioeconomic status and the distinction between modern versus traditional participation. We will revisit the implications of the various patterns of social inequalities at the end of this paper.

\section{Limitations}

Before discussing the complexity in conclusion, some limitations of this study were acknowledged. First, the cross-sectional nature of the VLV data does not enable a causal relationship between social participation and life satisfaction and the direction of their association to be established. A second limiting factor is the indicators used in this study. We examined social participation in terms of access to some practices. However, the intensity of practice would as well impact wellbeing (Morrow-Howell et al., 2003). This dimension requires further investigation. Similarly, among the SWB indicators, we studied its cognitive dimension using the Satisfaction with Life Scale. Affective dimensions or a eudemonic approach deserve consideration to understand better the various issues of social participation linked to SWB (on the threefold structure of SWB, see Vanhoutte, 2014). More so, studies examining various 
dimensions of SWB submitted possible differing association or mechanisms with social participation (Warr et al., 2004; Li et al., 2018).

Beyond specific indicators, a more ideological remark concerns measuring the social participation value through its association with SWB. As mentioned in the Introduction, this is a relatively new trend. In fact, until the 1980s retired wellbeing was a socio-political issue considered at a collective level, while individual (and consequently subjective) wellbeing emerged at the end of the 1990s as a new political ambition for old age (Collinet and Delalandre, 2014). In this context, the capacity to remain active became the condition for this wellbeing. The capability approach especially opposes this view as any utilitarianism conception of wellbeing, by defending a definition of wellbeing as the 'real freedom' individuals have to live the life they 'have reason to value' (Sen, 1999: 285). In addition to the issues of inequalities affecting lifestyle opportunities, the proponents of the capability theory are concerned with the adaptive preferences mechanism, whereby expectations would be lowered depending on the status and associated life opportunities. This would lead to reducing the cost of inequalities in terms of SWB and life satisfaction. Nonetheless, we think that examining life satisfaction as a component of SWB is coherent with the important investigation line in gerontology on older adults' adaptation strategies (e.g. Baltes and Baltes, 1990; Rowe and Kahn, 1997). In this context, the capability approach and critical gerontology have the merit to put in perspective and to underline the normative aspect behind both activation and SWB.

Finally, the focus of our study on Swiss data limits the generalisation of the results, since socio-cultural contexts can influence the forms of social participation as well as their links with satisfaction with life (Vogelsang, 2016). Nevertheless, we believe that studying Switzerland is informative as it poses a good example of both a wealthy and unequal society. It has one of the highest life expectancies and is one of the richest parts of the world, however, the life expectancy of the less-educated stagnates, and about 20 per cent of its older adults live below the poverty threshold (Oris et al., 2017; Remund et al., 2019). In addition, Switzerland has fully adopted the model of active ageing in its old-age policy (Conseil fédéral, 2007). Finally, the various Swiss regions make the country diverse (territorially, culturally, socioeconomically and even politically), reflecting in large part the diversity of northwest Europe. Overall, our findings on the links between life satisfaction and social participation conform with the various trends propounded in other national contexts, while having the advantage to remove barriers between research fields (e.g. family and personal relationships, formal public participation or leisure activities) and to link them explicitly to social inequalities. In this context, our results invite further study in other countries or an international comparative perspective.

\section{Diversity and social inequalities in social participation challenge active ageing}

Overall, our results highlight the particular significance of participation through involvement in institutionalised ties and/or sociability in private contexts. Following a critical perspective, they underline the existence of various social inequalities in the access to these forms of participation: more modern ones that are more valued in a social context promoting individualisation and self- 
realisation and in the context of ageing societies - are more socially stratified, showing an accumulation of advantages for an elite group of globally hyperactive older adults. In particular, those who represent the new cohorts of retired people - young old, more educated and in relatively better health (Remund et al., 2019) - can be opposed to the older ones who are much more dependent on family or religious circles to preserve some meaningful social participation. Furthermore, our results emphasise the importance of more community-based, traditional forms of participation: they are equal across the social strata and appear particularly crucial for the more vulnerable - and globally less-participative - older adult.

In this perspective, the oldest men from the popular classes seem particularly at risk of a lack of meaningful participation opportunities. While women are more frequently poor, living alone and facing health problems, they are simultaneously advantaged regarding friendship sociability and religious practices. This last activity is even more important for the older cohort and among the less educated. In addition, the fact that the oldest men constitute a small minority of the population contributes to their vulnerability, making their condition less visible.

Our results have important implications towards the 'active ageing' concept as a key issue in both scientific and political debates on ageing, linking social participation with wellbeing. Our study demonstrates an interest in adopting a broad and multifaceted definition of social participation and support literature defending the multidimensionality of the active ageing concept (Marsillas et al., 2017; Del Barrio et al., 2018). In particular, results underline that meaningful social participation activities are not necessarily the same from both an individual perspective (e.g. SWB) and from a societal one, as supported, for instance, through productive or even solidarity models of active ageing, which focus on the contribution of older people to society. Further, we showed that the dominant discourses of active ageing, which so often focus on the productive definition of social participation, or generally the level of practices through the promotion of physical activity (Del Barrio et al., 2018), contribute particularly to an elitist vision of ageing that is observed essentially among a minority of the older adults: the most socio-economically favoured. In this sense, we agree with other authors describing active ageing as a product of - built by and for - the upper class (Lakomý, 2020). In addition, the focus on formal public participation tends to promote a more masculine model of ageing (Baeriswyl, 2018).

Conversely, in the perspective of SWB, promoting participation should include efforts to allow each older adult to access the form that has meaning for him or her. In this context, private forms of sociability, which are more common among the older adults, or religious attendance, a practice important for more vulnerable categories, should be considered.

Such results raise questions for the future. Previous studies showed that in secularising Switzerland, as in most of the Western world, church attendance is decreasing across time and the birth cohorts (Agahi and Parker, 2005; Ajrouch et al., 2007; Broese van Groenou and Deeg, 2010; Baeriswyl, 2017). The transformations affecting family life are well-documented (Widmer, 2016). Conversely, the increasing importance of elective social ties, such as friendship, have been theoretically and empirically demonstrated (Allan, 2008; Baeriswyl, 2017). Collectively, these trends suggest a possible decline of meaningful participation chances for the most vulnerable who could face an additional accumulation of penalties. Further studies are 


\section{needed to understand better how social participation and its links with life satisfac- tion are changing and will be distributed among older adults.}

Acknowledgements. The authors are grateful to the Swiss National Science Foundation for its financial assistance. The authors are also grateful to the two anonymous reviewers for their careful reading and their valuable suggestions on this paper.

\section{Author contributions.}

MB participated in the data collection, formulated the research question, conceptualised the study, analysed the data and drafted the manuscript. MO supervised the data collection, helped in analysing and interpreting the data, and critically appraised and approved the final version of the paper.

Financial support. This work was supported by a Sinergia project (grant number CRSII1_129922/1) and the Swiss National Centre of Competence in Research LIVES - Overcoming Vulnerability: Life Course Perspectives (NCCR LIVES; grant number 51NF40-160590), which are both financed by the Swiss National Science Foundation.

Conflict of interest. The authors declare no conflicts of interest.

Ethical standards. All participants gave their written informed consent for inclusion in the study before participating. The present study was conducted in accordance with the Declaration of Helsinki, and the study protocol has been approved by the ethics commission of the Faculty of Psychology and Educational Sciences of the University of Geneva (project identification code CE_FPSE_14.10.2010). The database is available at the Swiss Centre of Expertise in the Social Sciences (https://forscenter.ch/).

\section{Notes}

1 Other studies distinguished eudemonic wellbeing as a third approach of SWB that stresses selfactualisation and autonomy: it appears closely related to life satisfaction among older adults (Jivraj et al., 2014; Vanhoutte, 2014).

2 The private/public distinction cannot be understood as 'a single paired opposition, but [as] a complex family of them, neither mutually reducible nor wholly unrelated' (Weintraub, 1997: 2).

3 See https://cigev.unige.ch/index.php?cID=754.

4 We distinguish here particularly who has access to the second or third pillar of the Swiss retirement system (for more details, see Streit, 2009), the economic vulnerability of people living only with the first pillar income having been demonstrated (Gabriel et al., 2015). This measure is thus used as a proxy for economic capital, the monthly income variable accounting for too many missing values (17\%).

5 The 'modern' dimension of these forms of participation, i.e. associative involvement and visiting friends, is similarly confirmed by our results on regional trends. Actually, they tend to be more practised in Geneva, which is typical of an urban, laic and socio-economically advanced context, in particular compared to Valais or Ticino, which are more conservative regions. At the opposite end and in coherence to the previous findings, church attendance and family sociability, considered to be more traditional forms of participation, are less frequent in Geneva.

\section{References}

Agahi N and Parker MG (2005) Are today's older people more active than their predecessors? Participation in leisure-time activities in Sweden in 1992 and 2002. Ageing \& Society 25, 925-941.

Ajrouch KJ, Akiyama H and Antonucci TC (2007) Cohort differences in social relations among the elderly. In Wahl HW, Tesch-Romer C and Hoff A (eds), New Dynamics in Old Age: Individual, Environmental, and Societal Perspectives. Amityville, NY: Baywood Publishers, pp. 43-63.

Allan G (2008) Flexibility, friendship, and family. Personal Relationships 15, 1-16. 
Amagasa S, Fukushima N, Kikuchi H, Oka K, Takamiya T, Odagiri Y and Inoue S (2017) Types of social participation and psychological distress in Japanese older adults: a five-year cohort study. PLOS ONE 12, e0175392.

Baars J, Dannefer D, Phillipson C and Walker A (2005) Introduction: Critical perspectives in social gerontology. In Baars J, Phillipson C and Dannefer D (eds), Aging, Globalization and Inequality: The New Critical Gerontology. New York, NY: Baywood, pp. 1-16.

Backes GM and Amrhein L (2008) Potenziale und Ressourcen des Alter(n)s im Kontext von sozialer Ungleichheit und Langlebikeit. In Künemund $\mathrm{H}$ and Schroeter KR (eds), Soziale Ungleichheiten und Kulturelle Unterschiede in Lebenslauf und Alter. Wiesbaden, Germany: VS Verlag für Sozialwissenschaften, pp. 71-84.

Baeriswyl M (2017) Participations sociales au temps de la retraite. Une approche des inégalités et évolutions dans la vieillesse. In Burnay $\mathrm{N}$ and Hummel C (eds), L'impensé des classes sociales dans le processus de vieillissement. Bern: Peter Lang, pp. 141-170.

Baeriswyl M (2018) L'engagement collectif des aînés au prisme du genre: évolutions et enjeux. Gérontologie et société 40, 53-78.

Baeriswyl M, Girardin $\mathbf{M}$ and Oris $\mathbf{M}$ (in press) Financial support given by older adults to family members: a configurational perspective. Journal of Demographic Economics.

Baker LA, Cahalin LP, Gerst K and Burr JA (2005) Productive activities and subjective well-being among older adults: the influence of number of activities and time commitment. Social Indicators Research 73, 431-458.

Baltes PB and Baltes MM (1990) Psychological perspectives on successful aging: the model of selective optimization with compensation. In Baltes PB and Baltes MM (eds), Successful Aging: Perspectives from the Behavioral Sciences. New York, NY: Cambridge University Press, pp. 1-34.

Barbabella F, Poli A and Kostakis I (2019) Statut économique et participation sociale: effets sur la qualité de vie des personnes âgées fragilisées. Retraite et société 81, 41-64.

Bath PA and Deeg D (2005) Social engagement and health outcomes among older people: introduction to a special section. European Journal of Ageing 2, 24-30.

Baumann M (2012) Les collectivités religieuses en mutation. Structures, identités et relations interreligieuses. In Pahud de Mortanges R, Bochinger C and Baumann M (eds), Religions, Etat et société. La Suisse entre sécularisation et diversité religieuse. Zurich: Editions Neue Zürcher Zeitung, pp. 21-74.

Beck U and Willms J (2004) Conversations with Ulrich Beck. Cambridge: Polity.

Bickel J-F and Cavalli S (2008) Activités de loisir et pratiques religieuses. In Lalive D'Epinay C and Spini D (eds), Les années fragiles: la vie au-delà de quatre-vingts ans. Quebec City, Canada: Les Presses de l'Université Laval, pp. 247-274.

Bickel J-F and Girardin Keciour M (2008) Remaining active: a boost for well-being? In Guilley E and Lalive D'Epinay C (eds), The Closing Chapters of Long Lives. Results from the 10-Year Swilsoo Study on the Oldest Old. New York, NY: Nova Science Publishers, pp. 115-128.

Bickel J-F, Lalive d'Epinay C and Vollenwyder N (2005) Changement et continuité dans les loisirs: une comparaison de cohortes. L'Année sociologique 55, 129-170.

Bidart C, Degenne A and Grossetti M (2011) La vie en réseau. Dynamique des relations sociales. Paris: Presses universitaires de France.

Blais MR, Vallerand RJ, Pelletier LG and Brière NM (1989) L'échelle de satisfaction de vie: validation canadienne-française du 'Satisfaction with Life Scale'. Canadian Journal of Behavioural Science/Revue canadienne des sciences du comportement 21, 210-223.

Blossfeld PN, Blossfeld GJ and Blossfeld HP (2015) Educational expansion and inequalities in educational opportunity: long-term changes for East and West Germany. European Sociological Review 31, 144-160.

Broese van Groenou MI and Deeg DJH (2010) Formal and informal social participation of the 'young-old' in the Netherlands in 1992 and 2002. Ageing \& Society 30, 445-465.

Campiche RJ (1996) Religion, statut social et identité féminine/Religion, social status and feminine identity. Archives des sciences sociales des religions 95, 69-94.

Campiche RJ and Kuzeawu AS (2014) Adultes aînés: les oubliés de la formation. Lausanne, Switzerland: Editions Antipodes.

Carr D and Moorman SM (2011) Social relations and aging. In Settersten RA and Angel JL (eds), Handbook of Sociology of Aging. New York, NY: Springer, pp. 145-160.

Chen C (2001) Aging and life satisfaction. Social Indicators Research 54, 57-79. 
Choi NG, Burr JA, Mutchler JE and Caro FG (2007) Formal and informal volunteer activity and spousal caregiving among older adults. Research on Aging 29, 99-124.

Choi K-S, Stewart R and Dewey M (2013) Participation in productive activities and depression among older Europeans: Survey of Health, Ageing and Retirement in Europe (SHARE). International Journal of Geriatric Psychiatry 28, 1157-1165.

Cingolani P (2012) Le temps fractionné. Multiactivité et création de soi. Paris: Armand Colin.

Collinet C and Delalandre M (2014) L'injonction au bien-être dans les programmes de prévention du vieillissement. L'Année sociologique 64, 445-467.

Conseil fédéral (2007) Stratégie en matière de politique de la vieillesse. Bern: Conseil fédéral. Available at https://www.bsv.admin.ch/dam/bsv/fr/dokumente/fgg/berichte-vorstoesse/br-bericht-strategie-schweizerische-alterspolitik.pdf.download.pdf/strategie_en_matieredepolitiquedelavieillesse.pdf.

Cumming E and Henry WE (1961) Growing Old: The Process of Disengagement. New York, NY: Basic Books.

Cutler SJ, Hendricks J and O’Neill G (2011) Civic engagement and aging. In Binstock RH and George LK (eds), Handbook of Aging and the Social Sciences. San Diego, CA: Academic Press, pp. 221-233.

Dannefer D (2020) Systemic and reflexive: foundations of cumulative dis/advantage and life-course processes. Journals of Gerontology: Psychological Sciences and Social Sciences 75B, 1249-1263.

Del Barrio E, Marsillas S, Buffel T, Smetcoren A-S and Sancho M (2018) From active aging to active citizenship: the role of (age) friendliness. Social Sciences 7, 134.

Diener E, Emmons RA, Larsen RJ and Griffin S (1985) The satisfaction with life scale. Journal of Personality Assessment 49, 71-75.

Dolan P, Peasgood T and White M (2008) Do we really know what makes us happy? A review of the economic literature on the factors associated with subjective well-being. Journal of Economic Psychology 29, 94-122.

Dorfman LT (2013) Leisure activities in retirement. In Wang M (ed.), The Oxford Handbook of Retirement. Oxford: Oxford University Press, pp. 339-353.

Douglas H, Georgiou A and Westbrook J (2017) Social participation as an indicator of successful aging: an overview of concepts and their associations with health. Australian Health Review 41, 455-462.

Duvoisin A (2020) Les origines du baby-boom en Suisse au prisme des parcours féminins. Bern: Peter Lang.

Einolf CJ (2009) Will the boomers volunteer during retirement? Comparing the baby boom, silent, and long civic cohorts. Nonprofit and Voluntary Sector Quarterly 38, 181-199.

Ellison CG (1991) Religious involvement and subjective well-being. Journal of Health and Social Behavior 32, 80-99.

Ellison CG, Boardman JD, Williams DR and Jackson JS (2001) Religious involvement, stress, and mental health: findings from the 1995 Detroit area study. Social Forces 80, 215-249.

European Commission (nd) Active Aging. Available at https:/lec.europa.eu/social/main.jsp? catId=1062\&langId=en.

Formosa M (2011) Critical educational gerontology: a third statement of first principles. International Journal of Education and Ageing 2, 317-332.

Formosa M (2012) European Union policy on older adult learning: a critical commentary. Journal of Aging \& Social Policy 24, 384-399.

Formosa M (2019) Active ageing through lifelong learning: the University of the Third Age. In Formosa M (ed.), The University of the Third Age and Active Ageing: European and Asian-Pacific Perspectives. Cham, Switzerland: Springer International Publishing, pp. 3-18.

Gabriel R, Oris M, Studer M and Baeriswyl M (2015) The persistence of social stratification? A life course perspective on old-age poverty in Switzerland. Swiss Journal of Sociology 41, 465-487.

George LK (2010) Still happy after all these years: research frontiers on subjective well-being in later life. Journals of Gerontology: Psychological Sciences and Social Sciences 65B, 331-339.

Giddens A (1991) Modernity and Self-identity: Self and Society in the Late Modern Age. Stanford, CA: Stanford University Press.

Gilmour H (2012) Social participation and the health and well-being of Canadian seniors. Health Reports 23. Available at https://www150.statcan.gc.ca/n1/pub/82-003-x/2012004/article/11720-eng.pdf.

Greenfield EA and Marks NF (2004) Formal volunteering as a protective factor for older adults' psychological well-being. Journals of Gerontology: Psychological Sciences and Social Sciences 59B, $258-624$. 
Grossetti M (2005) Where do social relations come from? A study of personal networks in the Toulouse area of France. Social Networks 27, 289-300.

Guilley E, Ghisletta P, Armi F, Berchtold A, Lalive d'Epinay C, Michel J-P and de Ribaupierre A (2008) Dynamics of frailty and ADL dependence in a five-year longitudinal study of octogenarians. Research on Aging 30, 299-317.

Gutiérrez M, Tomás JM, Galiana L, Sancho $\mathbf{P}$ and Cebrià MA (2013) Predicting life satisfaction of the Angolan elderly: a structural model. Aging \& Mental Health 17, 94-101.

Haslam SA, Jetten J, Postmes T and Haslam C (2009) Social identity, health and well-being: an emerging agenda for applied psychology. Applied Psychology 58, 1-23.

Helliwell JF and Putnam RD (2004) The social context of well-being. Philosophical Transactions: Biological Sciences 359, 1435-1446.

Honneth A (2004) Organized self-realization: some paradoxes of individualization. European Journal of Social Theory 7, 463-478.

Hornby-Turner YC, Peel NM and Hubbard RE (2017) Health assets in older age: a systematic review. BMJ Open 7, e013226.

Huxhold O, Miche M and Schüz B (2014) Benefits of having friends in older ages: differential effects of informal social activities on well-being in middle-aged and older adults. Journals of Gerontology: Psychological Sciences and Social Sciences 69B, 366-375.

Jivraj S, Nazroo J, Vanhoutte B and Chandola T (2014) Aging and subjective well-being in later life. Journals of Gerontology: Psychological Sciences and Social Sciences 69B, 930-941.

Joulain M, Martinent G, Taliercio A, Bailly N, Claude F and Kamel G (2019) Social and leisure activity profiles and well-being among the older adults: a longitudinal study. Aging \& Mental Health 23, 77-83.

Krause N (2010) Close companion friends, self-expression, and psychological well-being in late life. Social Indicators Research 95, 199-213.

Krüger H and Levy R (2001) Linking life courses, work, and the family: theorizing a not so visible nexus between women and men. Canadian Journal of Sociology/Cahiers canadiens de sociologie 26, 145-166.

Lakomý M (2020) Prevalence of activities in later life across European regions. Central European Journal of Public Policy 14, 14-27.

Lalive d'Epinay C, Bickel J-F, Maystre C and Vollenwyder N (2000) Vieillesses au fil du temps, 1979-1994. Une révolution tranquille. Lausanne, Switzerland: Réalités sociales.

Larivière N (2008) Analysis of the concept of social participation: definitions, illustration, dimensions of activity and indicators. Canadian Journal of Occupational Therapy/Revue canadienne d'ergothérapie 75, 114-127.

Laslett P (1987) The emergence of the third age. Ageing \& Society 7, 133-160.

Lee $\mathbf{S}$ and Choi $\mathbf{H}$ (2020) Impact of older adults' mobility and social participation on life satisfaction in South Korea. Asian Social Work and Policy Review 14, 4-10.

Levasseur M, Richard L, Gauvin L and Raymond E (2010) Inventory and analysis of definitions of social participation found in the aging literature: proposed taxonomy of social activities. Social Science \& Medicine 71, 2141-2149.

Li Y and Ferraro KF (2005) Volunteering and depression in later life: social benefit or selection processes? Journal of Health and Social Behavior 46, 68-84.

Li Y, Xu L, Min J, Chi I and Xie B (2016) Social participation and life satisfaction among widowed older adults in China. Journal of Gerontology \& Geriatric Research 5. Available at https://rc.library.uta.edu/utair/handle/10106/26481.

Li C, Jiang S, Li N and Zhang Q (2018) Influence of social participation on life satisfaction and depression among Chinese elderly: social support as a mediator. Journal of Community Psychology 46, 345-355.

Lim C and Putnam RD (2010) Religion, social networks, and life satisfaction. American Sociological Review 75, 914-933.

Ludwig C, Cavalli S and Oris M (2014) 'Vivre/Leben/Vivere': an interdisciplinary survey addressing progress and inequalities of aging over the past 30 years in Switzerland. Archives of Gerontology and Geriatrics 59, 240-248.

Lüscher K and Pillemer K (1998) Intergenerational ambivalence: a new approach to the study of parentchild relations in later life. Journal of Marriage and Family 60, 413-425. 
Marsillas S, De Donder L, Kardol T, van Regenmortel S, Dury S, Brosens D, Smetcoren A-S, Braña T and Varela J (2017) Does active ageing contribute to life satisfaction for older people? Testing a new model of active ageing. European Journal of Ageing 14, 295-310.

Mendes FR (2013) Active ageing: a right or a duty? Health Sociology Review 22, 174-185.

Moen P, Dempster-McClain D and Williams RM (1992) Successful aging: a life-course perspective on women's multiple roles and health. American Journal of Sociology 97, 1612-1638.

Monnot C (2013) Croire ensemble. Analyse institutionnelle du paysage religieux en Suisse. Zurich: Seismo.

Morrow-Howell N (2010) Volunteering in later life: research frontiers. Journals of Gerontology: Psychological Sciences and Social Sciences 65B, 461-469.

Morrow-Howell N, Hinterlong J, Rozario PA and Tang F (2003) Effects of volunteering on the well-being of older adults. Journals of Gerontology: Psychological Sciences and Social Sciences 58B, 137-145.

Moulaert T and Biggs S (2013) International and European policy on work and retirement: reinventing critical perspectives on active ageing and mature subjectivity. Human Relations 66, 23-43.

Narushima M, Liu J and Diestelkamp N (2018) Lifelong learning in active ageing discourse: its conserving effect on wellbeing, health and vulnerability. Ageing \& Society 38, 651-675.

Office fédéral de la statistique (OFS) (nd) Formation achevée la plus élevée: degré tertiaire, en 2012. Atlas statistique de la Suisse. Neuchâtel, Switzerland: OFS. Available at https://www.atlas.bfs.admin.ch/maps/ 13/fr/9320_136_131_3113/16571.html.

Oishi S, Diener E and Lucas RE (2018) Subjective well-being: the science of happiness and life satisfaction. In Snyder CR, Lopez SJ, Edwards LM and Marques SC (eds). The Oxford Handbook of Positive Psychology, 3rd Edn. New York, NY: Oxford University Press. Available online doi: 10.1093/ oxfordhb/9780199396511.013.14.

O’Neill G, Morrow-Howell N and Wilson SF (2011) Volunteering in later life: from disengagement to civic engagement. In Settersten RA and Angel JL (eds), Handbook of Sociology of Aging. New York, NY: Springer, pp. 333-350.

Oris M (2017) Vulnerability. A life course perspective. Revue de droit comparé du travail et de la sécurité sociale 4, 6-17.

Oris M, Guichard E, Nicolet M, Gabriel R, Tholomier A, Monnot C, Fagot D and Joye D (2016) Representation of vulnerability and the elderly. A total survey error perspective on the VLV survey. In Oris M, Roberts C, Joye D and Ernst-Stähli E (eds), Surveying Human Vulnerabilities Across the Life Course. Cham, Switzerland: Springer International Publishing, pp. 27-64.

Oris M, Gabriel R, Ritschard G and Kliegel M (2017) Long lives and old age poverty: social stratification and life-course institutionalization in Switzerland. Research in Human Development 14, 68-87.

Pavot W and Diener E (1993) Review of the satisfaction with life scale. Psychological Assessment 5, 164172.

Pavot W and Diener E (2009) Review of the satisfaction with life scale. In Diener E (ed.), Assessing Well-being. The Collected Works of Ed Diener. New York, NY: Springer, pp. 101-117.

Pennec S (2004) Les tensions entre engagements privés et engagements collectifs, des variations au cours du temps selon le genre et les groupes sociaux. Lien social et Politiques 51, 97-107.

Pinquart M and Sörensen S (2000) Influences of socioeconomic status, social network, and competence on subjective well-being in later life: a meta-analysis. Psychology and Aging 15, 187-224.

Potočnik K and Sonnentag S (2013) A longitudinal study of well-being in older workers and retirees: the role of engaging in different types of activities. Journal of Occupational and Organizational Psychology 86, 497-521.

Ramia I and Voicu M (in press) Life satisfaction and happiness among older Europeans: the role of active ageing. Social Indicators Research. Available online doi:10.1007/s11205-020-02424-6.

Raymond E, Gagné D, Sévigny A and Tourigny A (2008) La participation sociale des aînés dans une perspective de vieillissement en santé: réflexion critique appuyée sur une analyse documentaire. Direction de santé publique de l'Agence de la santé et des services sociaux de la Capitale-Nationale, Institut national de la santé publique du Québec, Centre d'excellence sur le vieillissement de Québec et Institut sur le vieillissement et la participation sociale des aînés de l'Université Laval. Available at https://www.inspq. qc.ca/pdf/publications/859_RapportParticipationSociale.pdf.

Remund A, Cullati S, Sieber S, Burton-Jeangros C and Oris M (2019) Longer and healthier lives for all? Successes and failures of a universal consumer-driven healthcare system, Switzerland, 1990-2014. International Journal of Public Health 64, 1173-1181. 
Rowe JW and Kahn RL (1987) Human aging: usual and successful. Science 237, 143-149.

Rowe JW and Kahn RL (1997) Successful aging. The Gerontologist 37, 433-440.

Ruggeri K, Garcia-Garzon E, Maguire Á, Matz S and Huppert FA (2020) Well-being is more than happiness and life satisfaction: a multidimensional analysis of 21 countries. Health and Quality of Life Outcomes 18(192).

Schwartz O (1990) Le monde privé des ouvriers: hommes et femmes du Nord. Paris: Presses Universitaires de France.

Sen A (1999) Development as Freedom. Oxford: Oxford University Press.

Simmel G (2009) Sociology: Inquiries into the Construction of Social Forms. Leiden, The Netherlands: Brill.

StataCorp (2011) Stata 12 Survey Data Reference Manual. College Station, TX: Stata Press.

Stevens NL and Van Tilburg TG (2011) Cohort differences in having and retaining friends in personal networks in later life. Journal of Social and Personal Relationships 28, 24-43.

Streit A (2009) Où en est la prévoyance-vieillesse? Sécurité sociale: Revue de l'Office fédéral des assurances sociales $2,69-73$.

Suanet B, van Tilburg TG and Broese van Groenou MI (2013) Nonkin in older adults' personal networks: more important among later cohorts? Journals of Gerontology: Psychological Sciences and Social Sciences 68B, 633-643.

van Dyk S, Lessenich S, Denninger T and Richter A (2013) The many meanings of 'active ageing'. Confronting public discourse with older people's stories. Recherches sociologiques et anthropologiques 44, 97-115.

Vanhoutte B (2014) The multidimensional structure of subjective well-being in later life. Journal of Population Ageing 7, 1-20.

Van Willigen M (2000) Differential benefits of volunteering across the life course. Journals of Gerontology: Psychological Sciences and Social Sciences 55B, 308-318.

Vogelsang EM (2016) Older adult social participation and its relationship with health: rural-urban differences. Health Place 42, 111-119.

Vozikaki M, Linardakis M, Micheli K and Philalithis A (2017) Activity participation and well-being among European adults aged 65 years and older. Social Indicators Research 131, 769-795.

Walker A (2002) A strategy for active ageing. International Social Security Review 55, 121-139.

Walker A (2009) Commentary: The emergence and application of active aging in Europe. Journal of Aging \& Social Policy 21, 75-93.

Wang H-X, Karp A, Winblad B and Fratiglioni L (2002) Late-life engagement in social and leisure activities is associated with a decreased risk of dementia: a longitudinal study from the Kungsholmen project. American Journal of Epidemiology 155, 1081-1087.

Warr P, Butcher V and Robertson I (2004) Activity and psychological well-being in older people. Aging \& Mental Health 8, 172-183.

Weintraub J (1997) The theory and politics of the public/private distinction. In Weintraub J and Kumar K (eds), Public and Private in Thought and Practice. Perspectives on a Grand Dichotomy. Chicago, IL: University of Chicago Press, pp. 1-42.

Widmer ED (2016) Family Configurations: A Structural Approach to Family Diversity. London: Routledge.

Wilson J and Musick M (1997) Who cares? Toward an integrated theory of volunteer work. American Sociological Review 62, 694-713.

World Health Organization (WHO) (2002) Active Ageing. A Policy Framework. Geneva: WHO. Available at http://whqlibdoc.who.int/hq/2002/WHO_NMH_NPH_02.8.pdf?ua=1.

Yuan H (2016) Structural social capital, household income and life satisfaction: the evidence from Beijing, Shanghai and Guangdong-Province, China. Journal of Happiness Studies 2, 569-586.

Zaidi A and Howse K (2017) The policy discourse of active ageing: some reflections. Journal of Population Ageing 10, 1-10.

Cite this article: Baeriswyl M, Oris M (2021). Social participation and life satisfaction among older adults: diversity of practices and social inequality in Switzerland. Ageing \& Society 1-25. https://doi.org/10.1017/ S0144686X21001057 